OPEN ACCESS

Edited by:

Min Suk Rhee,

Korea University, South Korea

Reviewed by:

Angelika Lehner,

University of Zurich, Switzerland Jesus L. Romalde,

University of Santiago

de Compostela, Spain

*Correspondence:

Stephen L. W. On

Stephen.on@lincoln.ac.nz

Specialty section: This article was submitted to

Food Microbiology,

a section of the journal

Frontiers in Microbiology

Received: 15 April 2019

Accepted: 22 July 2019

Published: 05 August 2019

Citation:

On SLW, Althaus D, Miller WG, Lizamore D, Wong SGL, Mathai AJ, Chelikani V and Carter GP (2019) Arcobacter cryaerophilus Isolated From New Zealand Mussels Harbor

a Putative Virulence Plasmid.

Front. Microbiol. 10:1802.

doi: 10.3389/fmicb.2019.01802

\section{Arcobacter cryaerophilus Isolated From New Zealand Mussels Harbor a Putative Virulence Plasmid}

\author{
Stephen L. W. On ${ }^{1 *}$, Damien Althaus ${ }^{1}$, William G. Miller ${ }^{2}$, Darrell Lizamore', \\ Samuel G. L. Wong ${ }^{1}$, Anso J. Mathai ${ }^{1}$, Venkata Chelikani ${ }^{1}$ and Glen P. Carter ${ }^{3}$ \\ ${ }^{1}$ Department of Wine, Food and Molecular Biosciences, Lincoln University, Lincoln, New Zealand, ${ }^{2}$ Produce Safety \\ and Microbiology Research Unit, Agricultural Research Service, U.S. Department of Agriculture, Albany, CA, United States, \\ ${ }^{3}$ Doherty Applied Microbial Genomics, The Peter Doherty Institute for Infection and Immunity, University of Melbourne, \\ Melbourne, VIC, Australia
}

A wide range of Arcobacter species have been described from shellfish in various countries but their presence has not been investigated in Australasia, in which shellfish are a popular delicacy. Since several arcobacters are considered to be emerging pathogens, we undertook a small study to evaluate their presence in several different shellfish, including greenshell mussels, oysters, and abalone (paua) in New Zealand. Arcobacter cryaerophilus, a species associated with human gastroenteritis, was the only species isolated, from greenshell mussels. Whole-genome sequencing revealed a range of genomic traits in these strains that were known or associated virulence factors. Furthermore, we describe the first putative virulence plasmid in Arcobacter, containing Iytic, immunoavoidance, adhesion, antibiotic resistance, and gene transfer traits, among others. Complete genome sequence determination using a combination of long- and short-read genome sequencing strategies, was needed to identify the plasmid, clearly identifying its benefits. The potential for plasmids to disseminate virulence traits among Arcobacter and other species warrants further consideration by researchers interested in the risks to public health from these organisms.

Keywords: Arcobacter cryaerophilus, shellfish, mussel, pathogen, virulence plasmid

\section{INTRODUCTION}

The genus Arcobacter currently contains 26 species (Pérez-Cataluña et al., 2018) of diverse origin, from cases of human diarrhea, and from livestock and aquatic environments, including shellfish (Ferreira et al., 2016; Ramees et al., 2017; Pérez-Cataluña et al., 2018). Indeed, in recent years, many new Arcobacter species have been recovered from shellfish, including Arcobacter bivalviorum (Levican et al., 2012), Arcobacter canalis (Pérez-Cataluña et al., 2018), Arcobacter molluscorum (Figueras et al., 2011a), Arcobacter ellisii (Figueras et al., 2011b), Arcobacter mytili (Collado et al., 2009) and Arcobacter venerupis (Levican et al., 2012). The relatively recent description of these species makes an evaluation of their potential threat to human health, or pathogenic potential, problematic. However, other species, including A. butzleri, Arcobacter cryaerophilus, and Arcobacter skirrowii, were among the first to be classified into the genus in the early 1990s (Vandamme et al., 1991, 1992) and are considered emerging pathogens warranting further study 
(International Commission on Microbiological Specifications for Foods [ICMSF], 2002; Ferreira et al., 2016; Ramees et al., 2017). Several studies have demonstrated the presence of these species in shellfish, in some cases in $100 \%$ of the samples examined (reviewed by Hsu and Lee, 2015).

In New Zealand, shellfish are an important component of the diet of, notably, indigenous (Mâori) New Zealanders (Ministry of Health, 2012). Shellfish can be eaten raw and so pose a special risk to consumers from a food safety perspective. Although the risks to human health from more established seafood pathogens such as Vibrio species have been investigated in New Zealand (Cruz et al., 2015, 2016), no study to our knowledge has previously investigated shellfish of Australasian origin for Arcobacter species. Nonetheless, emerging pathogenic Arcobacter species have been detected in various productionand domestic animals in New Zealand (McFadden et al., 2005; Bojanić et al., 2017, 2019).

We report here results from a small study in which locally sourced shellfish were examined for those Arcobacter species implicated as emerging pathogens, and isolates subjected to phenotypic and genotypic testing, including whole-genome sequencing (WGS).

\section{MATERIALS AND METHODS}

\section{Isolation and Phenotypic Characterization of Arcobacter spp. From New Zealand Shellfish}

Recovery of Arcobacter spp. was attempted from greenshell mussels (five batches from two regions in the South Island of 8-20 animals each), oysters (one batch from the Bluff region, $n=12$ ), and abalone (Paua, received frozen, exact place of origin unknown, one batch, $n=10$ ). Shellfish were harvested between 7.3.2016 and 23.5.2016 1 day prior to examination, using methods described previously (Levican et al., 2014) with minor modifications. Eight grams of shellfish meat were incubated overnight at room temperature $\left(18-22^{\circ} \mathrm{C}\right)$ in $80 \mathrm{ml}$ of Cefoperazone Amphotericin Teicoplanin (Oxoid Ltd., Basingstoke, United Kingdom) broth contained in $100 \mathrm{ml}$ Schott bottles. Subsequently, $100 \mu \mathrm{l}$ aliquots were inoculated onto blood agar plates, and incubated as prescribed (Levican et al., 2014) for up to 7 days at room temperature and $30^{\circ} \mathrm{C}$. Suspect colonies underwent phenotypic analyses, including: cell morphology assessment, catalase activity, indoxyl acetate hydrolysis, nitrate reduction, growth at $37^{\circ} \mathrm{C}$, and growth on $1 \%$ glycine, $4 \% \mathrm{NaCl}$-containing media, and Campylobacter BloodFree Selective Agar Base [Oxoid, CM0739]. The colonies were also antibiotyped with standardized methods as recommended (On et al., 1996, 2017). In brief, suspensions of 3-day old bacterial cultures were made in nutrient broth no. 2 (Oxoid Ltd.) of a density equating to ca. $10^{6}$ colony forming units $/ \mathrm{ml}$ and seeded onto Mueller-Hinton agar (Oxoid) supplemented with 5\% calf blood. Antibiotic disks were placed onto these plates and zones of inhibition determined after 3 days incubation at $30^{\circ} \mathrm{C}$ in aerobic conditions.

\section{Whole-Genome Sequencing, Annotation, and Plasmid Screening}

Genomic DNA was extracted and sequenced using both short(NextSeq 500 platform, Illumina, San Diego, CA, United States) and long-read (RS II platform, Pacific Biosciences, Menlo Park, CA, United States) technologies (Miller et al., 2018) for two isolates (M830MA and G13RTA); and the short read platform only for the remaining two strains (M830A and G18RTA), due to financial constraints. Genomes were assembled using SPAdes v3.9 and annotated using automated and manual approaches, as described elsewhere (Seemann, 2014; Miller et al., 2018). Genes with virulence potential were identified by reference to extant Genbank annotations and/or by crossreferencing to peer-reviewed publications. Plasmid carriage was confirmed using a QIAprep Spin Miniprep Kit (Qiagen, Hilden, Germany) with DNA content confirmed by Nanodrop (Thermo Fisher Scientific Ltd., Auckland, New Zealand), using the manufacturers recommendations.

\section{Phylogenetic and in silico DNA-DNA Hybridization Analyses}

Housekeeping gene sequences (16s rRNA, atpA, rpoB, and groEL) were extracted and compared with corresponding sequences from validly described Arcobacter spp. as described previously (On et al., 2017). In silico DNA-DNA hybridizations between our shellfish isolates and those of extant species were undertaken using Genome Blast Distance Phylogeny (GBDP) (Meier-Kolthoff et al., 2014), with parameters recommended for Arcobacter and related organisms (On et al., 2017).

\section{RESULTS}

\section{Isolation, Identification, and Antibiotyping of Strains}

Four Arcobacter spp. strains were recovered from two of the five batches of greenshell mussels examined, harvested in March (from the Kenepuru Sound growing area) and May 2016 (from the Admiralty Bay growing area), respectively. Arcobacters were not recovered from the other three mussel batches, or the oyster and Paua samples. Three strains were isolated in aerobic conditions and the fourth in microaerobic conditions. The phenotyping undertaken correlated well with corresponding data obtained for A. cryaerophilus (On et al., 1996), although nitrate was not reduced. Disk diffusion-based antibiotyping determined complete resistance to nalidixic acid $(30 \mu \mathrm{g})$ and vancomycin $(5 \mu \mathrm{g})$, and intermediate resistance to ceftaroline $(30 \mu \mathrm{g})$, chloramphenicol $(30 \mu \mathrm{g})$, cefoxitin $(30 \mu \mathrm{g})$ and tetracycline $(30 \mu \mathrm{g})$ in all strains.

Phylogenetic analysis of each of the housekeeping gene sequences used clustered New Zealand mussel isolates together with type and reference strains of $A$. cryaerophilus. The $16 \mathrm{~S}$ rRNA gene comparison is presented here as an exemplar (Figure 1). The whole-genome sequences of two isolates [M830A and M830MA (Genbank SNQM01000000 and CP026656, respectively)] from the same batch recovered under aerobic and microaerobic 


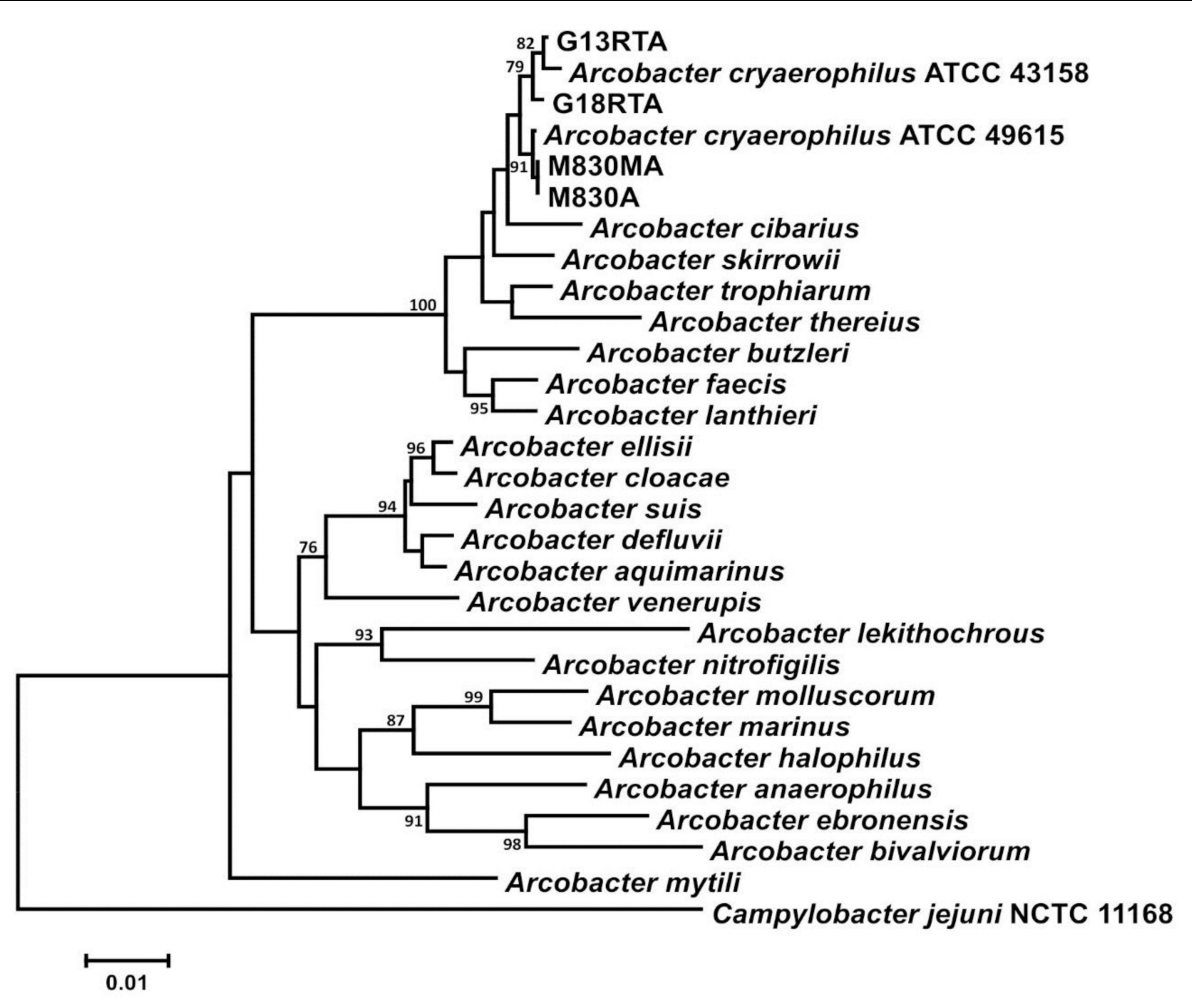

FIGURE 1 | 16S rRNA gene analysis of New Zealand Arcobacter isolates from mussels with other validly described species showing a clustering with type and reference strains of Arcobacter cryaerophilus.

conditions, respectively, possessed identical housekeeping gene sequences, protein profiles, and phenotypes, implying they represent the same clone. The remaining strains [G13 and G18 (Genbank CP026655 and SNQL01000000, respectively)] harbored unique genome sequences. Quantitative DNA-DNA hybridization values, as predicted from GBDP analyses of the whole-genome sequences, showed that the New Zealand mussel strains were $72.7-78.5 \%$ similar to those of a well-characterized reference strain (ATCC 49615) of A. cryaerophilus subgroup 2 (Vandamme et al., 1992). These values are well within accepted taxonomic boundaries for Arcobacter and related species, using the methods described (On et al., 2017). All our taxonomic data identify these strains as A. cryaerophilus.

\section{Genome and Plasmid Analysis}

Following Illumina sequencing, approximately $130 \times$ to $160 \times$ read depth was obtained per isolate and for PacBio sequencing, approximately $115 \times$ coverage was obtained. Genome sizes of the four isolates examined were each in the region of $2.1 \mathrm{MB}$ in size. Analysis of the complete genome of M830MA identified a putative virulence plasmid (BankIt2207814 M830MA_plasmid MK715471). Plasmid carriage was confirmed independently in this strain and in M830A (i.e., the clone recovered from the same batch using aerobic conditions) using the Qiaprep kit (data not shown). Bioinformatic analysis of the draft (produced using the short-read sequencing method) genome sequence determined for M830A did not identify a plasmid present. Plasmids were not detected in strains G13 or G18 either with the Qiaprep kit or bioinformatic analysis of the genome sequences.

Annotation of the $160,910 \mathrm{bp}$ plasmid sequence in strain M830MA identified 150 genes, 95 of which were not associated with any known function. Table 1 summarizes the size, location and predicted function of the remaining 55 genes, 15 were known, or associated with, virulence determinants such as adhesion, invasion, immunoavoidance, antimicrobial resistance (AMR), and biofilm formation. Several clusters of these genes are evident (Figure 2).

\section{DISCUSSION}

Of the Arcobacter spp. known, A. cryaerophilus is among the most commonly detected (Ferreira et al., 2016), and there have been various reports of $A$. cryaerophilus-associated human gastroenteritis, including in New Zealand (Mandisodza et al., 2012; Ferreira et al., 2016). Similarly, a number of foodand water-associated Arcobacter outbreaks have been described (reviewed by Ferreira et al., 2016). However, arcobacters are not routinely examined for, and their true prevalence remains undetermined. Nonetheless, various studies have shown them to be widely distributed in foods, including shellfish (Levican et al., 2014; Ferreira et al., 2016; Mottola et al., 2016), in which A. cryaerophilus has been found in up to $25 \%$ of mussels and clams examined (Mottola et al., 2016). Similar 
TABLE 1 | List of genes identified on the A. cryaerophilus virulence plasmid, showing predicted size, location, and function.

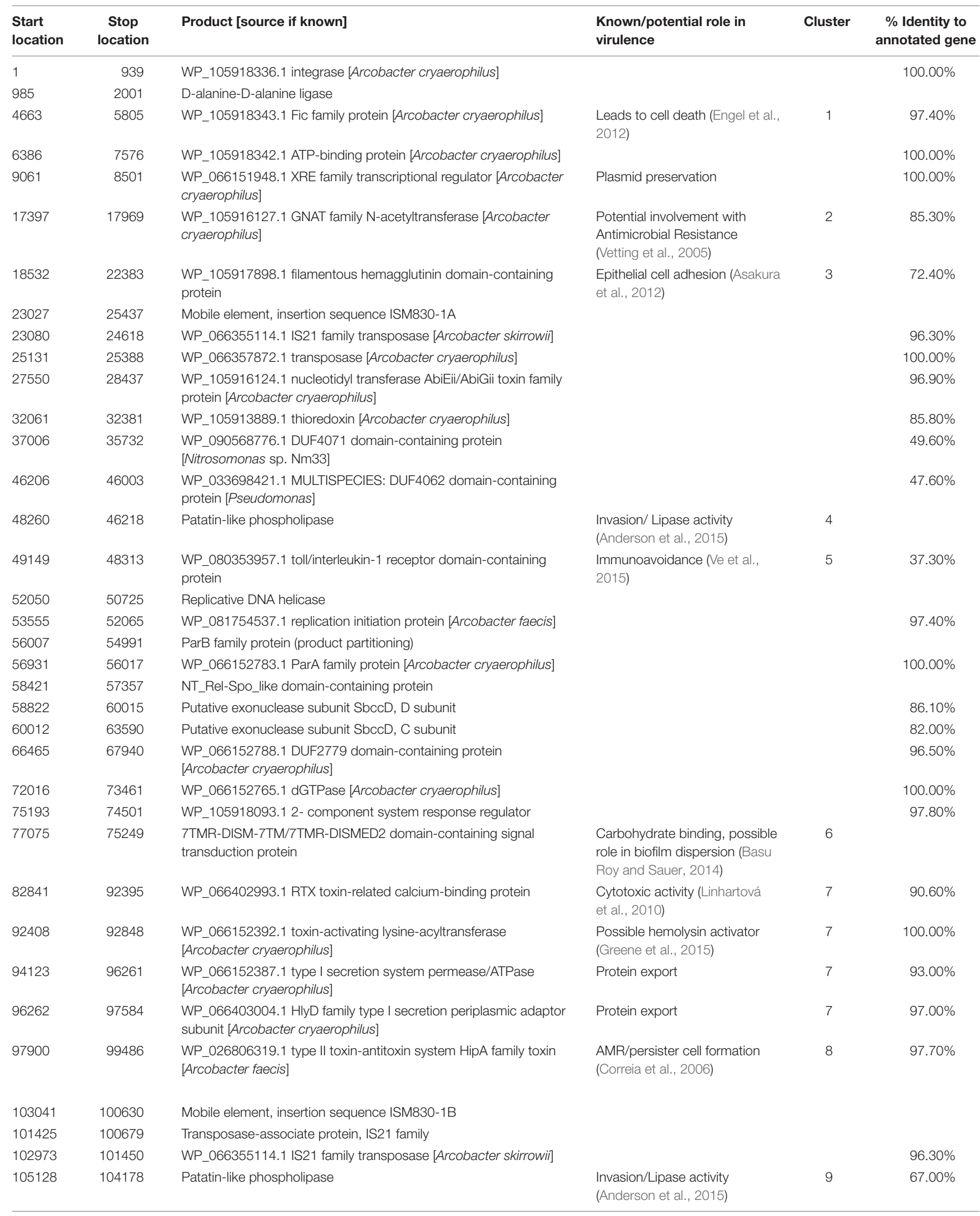


TABLE 1 | Continued

\begin{tabular}{|c|c|c|c|c|c|}
\hline $\begin{array}{l}\text { Start } \\
\text { location }\end{array}$ & $\begin{array}{c}\text { Stop } \\
\text { location }\end{array}$ & Product [source if known] & $\begin{array}{l}\text { Known/potential role in } \\
\text { virulence }\end{array}$ & Cluster & $\begin{array}{l}\% \text { Identity to } \\
\text { annotated gene }\end{array}$ \\
\hline 105545 & 106747 & WP_009379108.1 nucleotidyltransferase [Bilophila sp. 4_1_30] & & & $50.50 \%$ \\
\hline 107987 & 107631 & Toxin-antitoxin system, antitoxin component, RnIB family & & & \\
\hline 109038 & 107974 & Toxin-antitoxin system, antitoxin component, RnIA family & & & \\
\hline 110430 & 111521 & Site-specific recombinase & & & \\
\hline 119887 & 120141 & $\begin{array}{l}\text { WP_105918348.1 XRE family transcriptional regulator [Arcobacter } \\
\text { cryaerophilus] }\end{array}$ & & & $97.60 \%$ \\
\hline 127306 & 129717 & Mobile element, insertion sequence IS830-1C & & & \\
\hline 127374 & 128897 & WP_066355114.1 IS21 family transposase [Arcobacter skirrowii] & & & $96.30 \%$ \\
\hline 128922 & 129668 & WP_046996155.1 MULTISPECIES: transposase [Arcobacter] & & & $94.00 \%$ \\
\hline 131416 & 133359 & $\begin{array}{l}\text { WP_090294727.1 DUF4365 domain-containing protein [Muricauda } \\
\text { zhangzhouensis] }\end{array}$ & & & $29.10 \%$ \\
\hline 137132 & 136389 & $\begin{array}{l}\text { WP_090938743.1 TIR domain-containing protein [Azotobacter } \\
\text { beijerinckil] }\end{array}$ & $\begin{array}{l}\text { Immunoavoidance (Ve et al., } \\
\text { 2015) }\end{array}$ & 10 & $70.40 \%$ \\
\hline 138225 & 137221 & $\begin{array}{l}\text { WP_015487510.1 DUF4917 domain-containing protein } \\
\text { [Thalassolituus oleivorans] }\end{array}$ & & & $82.00 \%$ \\
\hline 140934 & 140371 & $\begin{array}{l}\text { WP_066152761.1 EamA/RhaT family transporter [Arcobacter } \\
\text { cryaerophilus] }\end{array}$ & & & $93.60 \%$ \\
\hline 141676 & 141299 & $\begin{array}{l}\text { WP_066152763.1 AraC family transcriptional regulator [Arcobacter } \\
\text { cryaerophilus] }\end{array}$ & & & $100.00 \%$ \\
\hline 142281 & 142844 & $\begin{array}{l}\text { WP_066152060.1 recombinase family protein [Arcobacter } \\
\text { cryaerophilus] }\end{array}$ & & & $98.90 \%$ \\
\hline 148254 & 150416 & Glycosyl hydrolase & & & \\
\hline 152741 & 152118 & DUF4263 domain-containing protein & & & \\
\hline 154436 & 154597 & Alpha/beta hydrolase & Invasion/Lipase activity & 11 & \\
\hline 157284 & 158967 & Patatin-like phospholipase & $\begin{array}{l}\text { Invasion/Lipase activity } \\
\text { (Anderson et al., 2015) }\end{array}$ & 11 & \\
\hline 159486 & 160694 & Site-specific tyrosine recombinase, phage integrase family & & & \\
\hline
\end{tabular}

Virulence gene clusters are labeled 1-12 according to location and function. Pseudogenes and genes coding for hypothetical proteins are not listed.

studies in India have identified other Arcobacter spp. in shellfish but not A. cryaerophilus (Laishram et al., 2016; Rathlavath et al., 2017). These studies, together with this report, indicate that the prevalence and distribution of different Arcobacter species varies from nation to nation. We note here that our isolation methods were aimed at recovering mainly species implicated as emerging pathogens, and thus the presence of other, environmentally associated species cannot be discounted. However, we can confirm that A. cryaerophilus occurs in shellfish from Mediterranean and New Zealand waters.

We believe our study is the first to describe Arcobacter spp. in Australasian shellfish and the first to identify a putative virulence plasmid in this group. Previous studies have examined arcobacters of human and animal origin for plasmids; where found, virulence attributes have not been identified (Harrass et al., 1998; Douidah et al., 2014). References validating genes identified on the plasmid described here as virulence determinants are given in Table 1. In wastewater environments, arcobacters have been described as "keystone members ...p potentially involved in cross-border exchanges between distant Grampositive and Gram-negative phyla" (Jacquiod et al., 2017). Our isolates were not recovered from areas exposed to wastewater contamination, but this does not preclude the potential for genetic exchange in their natural environments. Various genes identified on the plasmid reported here are involved with genetic movement and integration (Table 1). Given that our understanding of horizontal gene transfer mechanisms is not exhaustive (Toussaint and Chandler, 2012), the potential of intra- and interspecies transference of virulence attributes in food production environments is supported, with implications for food safety and public health. The presence of an acetyltransferase-coding gene associated (albeit not exclusively) with AMR (Vetting et al., 2005) is noteworthy, given the dramatic increase in AMR among many bacterial species, and the role that horizontal gene transfer plays in this process (World Health Organisation [WHO], 2015). The presence of other AMR (and additional pathogenic) traits in our A. cryaerophilus genomes (Table 2) may also represent a potential reservoir for wider gene transfer to other microorganisms.

The World Health Organization has emphasized the need for improved understanding of mechanisms of antibiotic resistance appertaining to food and water consumption (World Health Organisation [WHO], 2015). As the evidently first description of a putative virulence plasmid in arcobacters found in shellfish, this study extends our knowledge of potential AMR reservoirs. It is worth noting that our initial observation was made only through complete genome analysis; the use of draft genomes may overlook plasmid carriage, resulting in underreporting of important attributes. Land et al. (2014) determined quality metrics for 32,000 publicly available whole genome sequences, finding some $10 \%$ of these were of a questionable standard. Their study found completed genome sequences overwhelmingly 


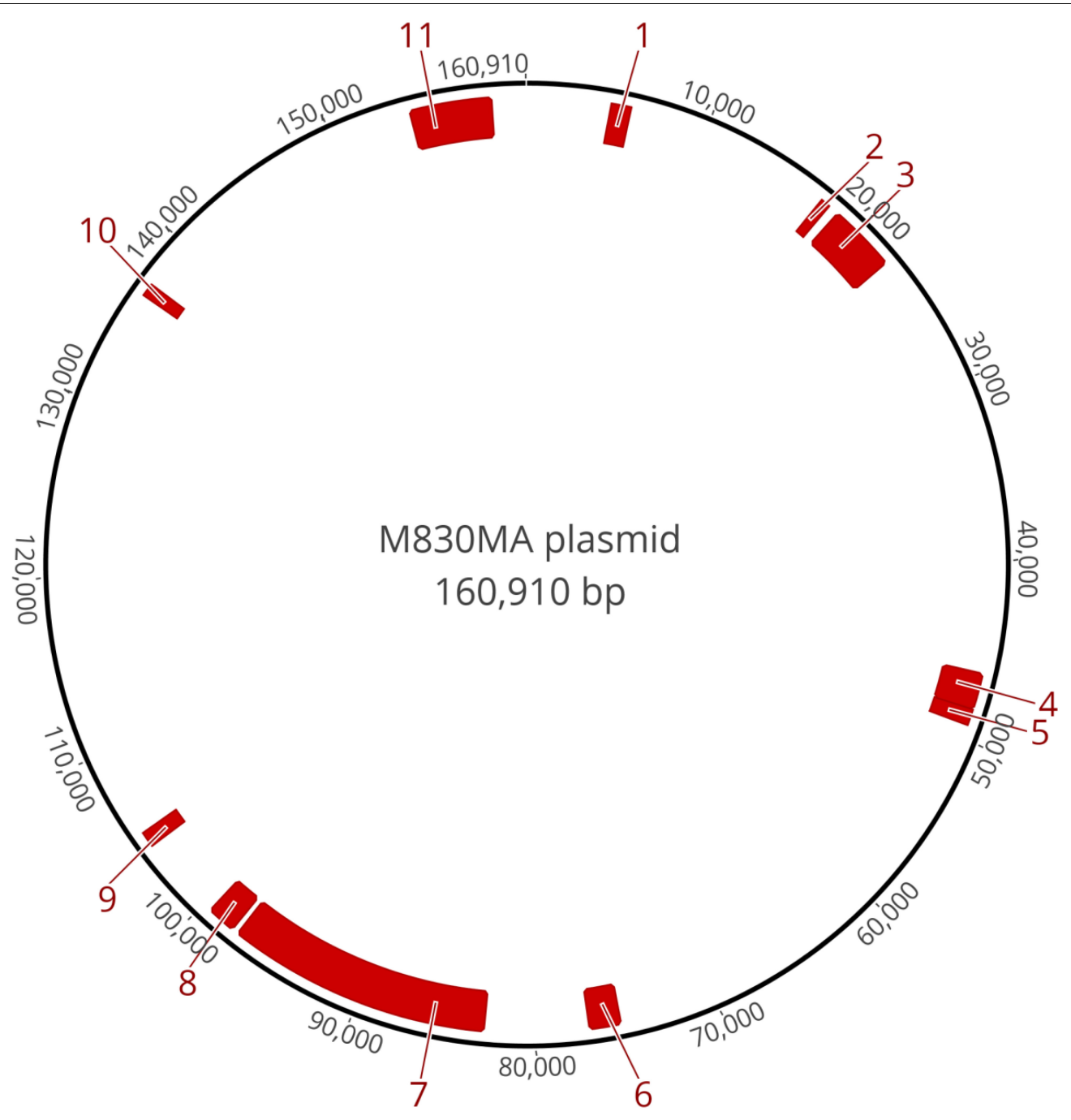

FIGURE 2 | Schematic of the circularized plasmid sequence and position of the gene clusters that are associated with putative virulence traits, as annotated in Table 1.

attained higher quality scores. Moreover, a subsequent study concluded that sequencing technologies generating shorter sequence reads (i.e., the genome sequence is encompassed in many contiguous fragments) present major difficulties for bioinformatics algorithms seeking to analyze such data (Land et al., 2015). Taken together, it is perhaps not surprising that our study only identified the putative virulence plasmid described here when complementary approaches for generating the complete genome sequence were used. Short-read second generation sequencing remains the most commonly used and cost-effective genome sequencing strategy for bacterial genomes (Land et al., 2015), but as our study indicates, the reduced financial cost can come at a price for biological data that may be of significance.

The pathogenesis of Arcobacter infections is poorly understood, despite their long association with human disease (Ferreira et al., 2016). Our A. cryaerophilus strains possessed 63-76 genes with known or putative virulence function (Table 2), in addition to those identified on the plasmid. Most functions are conserved between strains and include features for motility and adhesion, heme acquisition, hemolysin or toxin production, and various traits associated with AMR: a feature for which arcobacters are especially noted (On et al., 1996; Ferreira et al., 2016). The importance of this finding is pertinent, given that shellfish are often consumed with minimal treatment.

In summary, we have confirmed for the first time that New Zealand shellfish may harbor emerging pathogenic Arcobacter species that have been isolated from cases of human gastroenteritis. Further studies are required to determine more comprehensively the prevalence and distribution of these bacteria for a more complete risk assessment. Of more significance may be the observation that arcobacters may harbor plasmids that contain genes encoding for a variety of virulence and related functions, including those associated with AMR, invasion, immunoavoidance and cytotoxicity. We have determined that the carriage of such plasmids may not always be 
TABLE 2 | Annotation, predicted functions and distribution among shellfish A. cryaerophilus strains of virulence-associated genes.

\begin{tabular}{|c|c|c|c|}
\hline Annotation & Function & Virulence trait & Strains $^{a}$ \\
\hline flaA & Flagellin A & Motility and/or adhesion & M830MA \\
\hline Flagellar assembly protein $\mathrm{H}$ & Flagellar assembly protein $\mathrm{H}$ & Motility and/or adhesion & G13RTA, M830MA \\
\hline Flagellar basal body rod modification protein & Flagellar basal body rod modification protein & Motility and/or adhesion & G13RTA, M830MA \\
\hline Flagellar basal body rod protein FlgG & Flagellar basal body rod protein FlgG & Motility and/or adhesion & G13RTA, M830MA \\
\hline Flagellar basal body-associated protein FliL & Flagellar basal body-associated protein FliL & Motility and/or adhesion & M830MA \\
\hline Flagellar biosynthesis protein FliR & Flagellar biosynthesis protein FliR & Motility and/or adhesion & G13RTA, M830MA \\
\hline Flagellar filament $33 \mathrm{kDa}$ core protein & Flagellar filament $33 \mathrm{kDa}$ core protein & Motility and/or adhesion & G13RTA, G18RTA \\
\hline Flagellar hook-associated protein FlgL & Flagellar hook-associated protein FlgL & Motility and/or adhesion & G13RTA, M830MA \\
\hline Flagellar hook-length control protein FliK & Flagellar hook-length control protein Flik & Motility and/or adhesion & G13RTA, M830MA \\
\hline Flagellar motor switch protein & Flagellar motor switch protein & Motility and/or adhesion & G13RTA, M830MA \\
\hline Flagellin $N$-methylase & Flagellin $N$-methylase & Motility and/or adhesion & G13RTA, M830MA \\
\hline$f \lg B$ & Flagellar basal body rod protein FlgB & Motility and/or adhesion & G13RTA, G18RTA, M830MA \\
\hline flgC & Flagellar basal-body rod protein FlgC & Motility and/or adhesion & G13RTA, G18RTA, M830MA \\
\hline flgE1 & Flagellar hook protein FlgE & Motility and/or adhesion & G13RTA, G18RTA, M830MA \\
\hline$f l g G$ & Flagellar basal-body rod protein FlgG & Motility and/or adhesion & G13RTA, G18RTA, M830MA \\
\hline $\mathrm{flgH}$ & Flagellar L-ring protein & Motility and/or adhesion & G13RTA, G18RTA, M830MA \\
\hline flgl & Flagellar P-ring protein & Motility and/or adhesion & G13RTA, G18RTA, M830MA \\
\hline flgK & Flagellar hook-associated protein 1 & Motility and/or adhesion & G13RTA, G18RTA, M830MA \\
\hline flhA & Flagellar biosynthesis protein FlhA & Motility and/or adhesion & G13RTA, G18RTA, M830MA \\
\hline flhB1 & Flagellar biosynthetic protein FlhB & Motility and/or adhesion & G13RTA, G18RTA, M830MA \\
\hline flhF & Flagellar biosynthesis protein FlhF & Motility and/or adhesion & G13RTA, G18RTA, M830MA \\
\hline fliD & Flagellar hook-associated protein 2 & Motility and/or adhesion & G13RTA, G18RTA, M830MA \\
\hline fliE & Flagellar hook-basal body complex protein FliE & Motility and/or adhesion & G13RTA, G18RTA, M830MA \\
\hline fliF & Flagellar M-ring protein & Motility and/or adhesion & G13RTA, G18RTA, M830MA \\
\hline fliG & Flagellar motor switch protein FliG & Motility and/or adhesion & G13RTA, G18RTA, M830MA \\
\hline flil & Flagellum-specific ATP synthase & Motility and/or adhesion & G13RTA, G18RTA, M830MA \\
\hline flim & Flagellar motor switch protein FliM & Motility and/or adhesion & G13RTA, G18RTA, M830MA \\
\hline fliN1 & Flagellar motor switch protein FliN & Motility and/or adhesion & G13RTA, G18RTA, M830MA \\
\hline fliP & Flagellar biosynthetic protein FliP & Motility and/or adhesion & G13RTA, G18RTA, M830MA \\
\hline fliQ & Flagellar biosynthetic protein FliQ & Motility and/or adhesion & G13RTA, G18RTA, M830MA \\
\hline flis & Flagellar protein FliS & Motility and/or adhesion & G13RTA, G18RTA, M830MA \\
\hline fliW2 & Flagellar assembly factor FliW2 & Motility and/or adhesion & G13RTA, G18RTA, M830MA \\
\hline hag & Flagellin & Motility and/or adhesion & G13RTA, G18RTA \\
\hline $\operatorname{mot} B$ & Motility protein B & Motility and/or adhesion & G18RTA \\
\hline$y \mid x H$ & Flagellum site-determining protein $\mathrm{YlXH}$ & Motility and/or adhesion & G13RTA, G18RTA, M830MA \\
\hline acrB & Multidrug efflux pump subunit AcrB & Antimicrobial resistance & G13RTA, G18RTA, M830MA \\
\hline adh2 & Long-chain-alcohol dehydrogenase 2 & Antimicrobial resistance & G18RTA \\
\hline $\operatorname{arn} A$ & Bifunctional polymyxin resistance protein ArnA & Antimicrobial resistance & G13RTA \\
\hline $\operatorname{ars} B$ & Arsenical pump membrane protein & Antimicrobial resistance & G18RTA \\
\hline $\operatorname{arsC1}$ & Glutaredoxin arsenate reductase & Antimicrobial resistance & G18RTA \\
\hline $\operatorname{arsC2}$ & Arsenate reductase & Antimicrobial resistance & G18RTA \\
\hline$b c r$ & Bicyclomycin resistance protein & Antimicrobial resistance & G13RTA, M830MA \\
\hline bepC & Outer membrane efflux protein BepC & Antimicrobial resistance & G18RTA \\
\hline bepD & Efflux pump periplasmic linker BepD & Antimicrobial resistance & G18RTA \\
\hline bepE & Efflux pump membrane transporter BepE & Antimicrobial resistance & G13RTA, G18RTA, M830MA \\
\hline bepF & Efflux pump periplasmic linker BepF & Antimicrobial resistance & G13RTA, M830MA \\
\hline Enterobactin exporter EntS & Enterobactin exporter EntS & Antimicrobial resistance & G13RTA \\
\hline hсpA & Beta-lactamase HcpA & Antimicrobial resistance & M830MA \\
\hline hсpC & Putative beta-lactamase $\mathrm{HcpC}$ & Antimicrobial resistance & G13RTA, M830MA \\
\hline ImrA & $\begin{array}{l}\text { Multidrug resistance ABC transporter } \\
\text { ATP-binding and permease protein }\end{array}$ & Antimicrobial resistance & G13RTA \\
\hline marA & Multiple antibiotic resistance protein MarA & Antimicrobial resistance & M830MA \\
\hline$m d t B$ & Multidrug resistance protein MdtB & Antimicrobial resistance & G13RTA, G18RTA, M830MA \\
\hline $\operatorname{mexA}$ & Multidrug resistance protein MexA & Antimicrobial resistance & G13RTA, G18RTA, M830MA \\
\hline
\end{tabular}


TABLE 2 | Continued

\begin{tabular}{|c|c|c|c|}
\hline Annotation & Function & Virulence trait & Strains $^{a}$ \\
\hline $\operatorname{mex} B$ & Multidrug resistance protein MexB & Antimicrobial resistance & G13RTA, G18RTA, M830MA \\
\hline $\operatorname{mrdA}$ & Penicillin-binding protein 2 & Antimicrobial resistance & G13RTA, G18RTA, M830MA \\
\hline$p b p F$ & Penicillin-binding protein 1F & Antimicrobial resistance & G13RTA, G18RTA \\
\hline $\begin{array}{l}\text { Putative multidrug export } \\
\text { ATP-binding/permease protein }\end{array}$ & Putative multidrug export ATP-binding/permease protein & Antimicrobial resistance & G13RTA, G18RTA \\
\hline $\operatorname{srpC}$ & Putative chromate transport protein & Antimicrobial resistance & G18RTA \\
\hline $\operatorname{ttg} A$ & Putative efflux pump periplasmic linker TtgA & Antimicrobial resistance & G13RTA, G18RTA, M830MA \\
\hline $\operatorname{ttg} C$ & Putative efflux pump outer membrane protein TtgC & Antimicrobial resistance & G13RTA, M830MA \\
\hline $\operatorname{ttg} l$ & Toluene efflux pump outer membrane protein Ttgl & Antimicrobial resistance & G18RTA \\
\hline$y k k D$ & Multidrug resistance protein YkkD & Antimicrobial resistance & G18RTA \\
\hline btuB & Vitamin B12 transporter BtuB & Fe acquisition & G18RTA \\
\hline $\mathrm{fbpC}$ & Fe(3+) ions import ATP-binding protein FbpC & Fe acquisition & G13RTA \\
\hline Ferredoxin-NADP reductase & Ferredoxin-NADP reductase & Fe acquisition & G13RTA \\
\hline futA1 & Iron uptake protein A1 & Fe acquisition & G13RTA \\
\hline Gram-negative bacterial TonB protein & Gram-negative bacterial TonB protein & Fe acquisition & M830MA \\
\hline hemE & Uroporphyrinogen decarboxylase & Fe acquisition & G18RTA \\
\hline hemH1 & Ferrochelatase & Fe acquisition & G18RTA \\
\hline hmuT & Hemin-binding periplasmic protein HmuT & Fe acquisition & G13RTA, G18RTA, M830MA \\
\hline hmuU & Hemin transport system permease protein HmuU & Fe acquisition & G13RTA, G18RTA, M830MA \\
\hline hmuV & Hemin import ATP-binding protein HmuV & Fe acquisition & G13RTA, G18RTA \\
\hline hssS & Heme sensor protein HssS & Fe acquisition & G13RTA, G18RTA, M830MA \\
\hline$h \times u A$ & Heme/hemopexin-binding protein & Fe acquisition & G13RTA, M830MA \\
\hline$h \times u B$ & Heme/hemopexin transporter protein & Fe acquisition & G13RTA, M830MA \\
\hline isdE & High-affinity heme uptake system protein IsdE & Fe acquisition & G18RTA \\
\hline $\operatorname{tdh} A$ & TonB-dependent heme receptor A & Fe acquisition & G13RTA \\
\hline esiB1 & Secretory immunoglobulin A-binding protein EsiB & Immunoavoidance & G18RTA \\
\hline Plasmid stabilization system protein & Plasmid stabilization system protein & Plasmid stabilization & G13RTA \\
\hline virF & Virulence regulon transcriptional activator VirF & Virulence regulator & G18RTA \\
\hline epsF & Type II secretion system protein F & Toxin secretion & G13RTA \\
\hline$h \times c R$ & Putative type II secretion system protein HxcR & Toxin secretion & G13RTA \\
\hline prsE & Type I secretion system membrane fusion protein PrsE & Toxin secretion & G18RTA \\
\hline $\begin{array}{l}\text { Putative two-component membrane } \\
\text { permease complex subunit SMU 747c }\end{array}$ & $\begin{array}{l}\text { Putative two-component membrane permease complex } \\
\text { subunit SMU_747c }\end{array}$ & Toxin secretion & G18RTA \\
\hline bvgS1 & Virulence sensor protein BvgS & Virulence gene regulation & M830MA \\
\hline bvgS2 & Virulence sensor protein BvgS & Virulence gene regulation & M830MA \\
\hline bvgS3 & Virulence sensor protein BvgS & Virulence gene regulation & M830MA \\
\hline
\end{tabular}

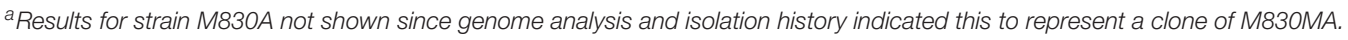

recognized where only draft (incomplete) genome sequences are determined. Additional studies are needed to assess the widerand longer-term implications of these results.

\section{DATA AVAILABILITY}

The datasets generated for this study can be found in Genbank, SNQM01000000, SNQL01000000, CP026655, CP026656, and Bankit2207814 M830_plasmid MK715471.

\section{AUTHOR CONTRIBUTIONS}

SO conceived and coordinated the study and wrote the manuscript. DA isolated the strains described. WM supplied reference whole genome sequences, undertook the phylogenetic analysis, and provided annotation of the plasmid. DL undertook genome annotation and complementary plasmid annotation. SW phenotyped the strains. AM antibiotyped the strains. VC extracted genomic DNA for sequencing and screened isolates for plasmids. GC determined the genome and plasmid sequences for the strains and provided the assemblies.

\section{ACKNOWLEDGMENTS}

The Lincoln University Harvest Fund is thanked for funding the genome sequencing. Nigel Harris, Stuart Berryman (Allied Fisheries Ltd., Christchurch, New Zealand), and Rodney Tribe 
(Ngâi Tahu Seafood, New Zealand) are thanked for their generous provision of the shellfish examined. Nigel Harris is also thanked for helpful discussions and providing the

\section{REFERENCES}

Anderson, D. M., Sato, H., Dirck, A. T., Feix, J. B., and Frank, D. W. (2015). Ubiquitin activates patatin-like phospholipases from multiple bacterial species. J. Bacteriol. 197, 529-541. doi: 10.1128/JB.02402-14

Asakura, H., Brüggemann, H., Sheppard, S. K., Ekawa, T., Meyer, T. F., Yamamoto, S., et al. (2012). Molecular evidence for the thriving of Campylobacter jejuni ST-4526 in Japan. PLoS One. 7:e48394. doi: 10.1371/journal.pone.004 8394

Basu Roy, A., and Sauer, K. (2014). Diguanylate cyclase NicD-based signalling mechanism of nutrient-induced dispersion by Pseudomonas aeruginosa. Mol. Microbiol. 94, 771-793. doi: 10.1111/mmi.12802

Bojanić, K., Midwinter, A. C., Marshall, J. C., Biggs, P. J., and Acke, E. (2019). Isolation of emerging Campylobacter species in working farm dogs and their frozen home-killed raw meat diets. J. Vet. Diagn. Invest. 31, 23-32. doi: 10.1177/ 1040638718820082

Bojanić, K., Midwinter, A. C., Marshall, J. C., Rogers, L. E., Biggs, P. J., and Acke, E. (2017). Isolation of campylobacter spp. from client-owned dogs and cats, and retail raw meat pet food in the manawatu, New Zealand. Zoonoses Public Health 64, 438-449. doi: 10.1111/zph.12323

Collado, L., Cleenwerck, I., Van Trappen, S., De Vos, P., and Figueras, M. J. (2009). Arcobacter mytili sp. nov., an indoxyl acetate-hydrolysis-negative bacterium isolated from mussels. Int. J. Syst. Evol. Microbiol. 59, 1391-1396. doi: 10.1099/ ijs.0.003749-0

Correia, F. F., D’Onofrio, A., Rejtar, T., Li, L., Karger, B. L., Makarova, K., et al. (2006). Kinase activity of overexpressed HipA is required for growth arrest and multidrug tolerance in Escherichia coli. J. Bacteriol. 188, 8360-8367. doi: 10.1128/jb.01237-06

Cruz, C. D., Chycka, M., Hedderley, D., and Fletcher, G. C. (2016). Prevalence, characteristics and ecology of Vibrio vulnificus found in New Zealand shellfish. J. Appl. Microbiol. 120, 1100-1107. doi: 10.1111/jam.13064

Cruz, C. D., Hedderley, D., and Fletcher, G. C. (2015). Long-term study of Vibrio parahaemolyticus prevalence and distribution in New Zealand shellfish. Appl. Environ. Microbiol. 81, 2320-2327. doi: 10.1128/AEM.040204014

Douidah, L., De Zutter, L., Van Nieuwerburgh, F., Deforce, D., Ingmer, H., Vandenberg, O., et al. (2014). Presence and analysis of plasmids in human and animal associated Arcobacter species. PLoS One 20:e85487. doi: 10.1371/journal. pone. 0085487

Engel, P., Goepfert, A., Stanger, F. V., Harms, A., Schmidt, A., Schirmer, T., et al. (2012). Adenylylation control by intra- or intermolecular active-site obstruction in fic proteins. Nature 482, 107-110. doi: 10.1038/nature10729

Ferreira, S., Queiroz, J. A., Oleastro, M., and Domingues, F. C. (2016). Insights in the pathogenesis and resistance of Arcobacter: a review. Crit. Rev. Microbiol. 42, 364-383. doi: 10.3109/1040841X.2014.954523

Figueras, M. J., Collado, L., Levican, A., Perez, J., Solsona, M. J., and Yustes, C. (2011a). Arcobacter molluscorum sp. nov., a new species isolated from shellfish. Syst. Appl. Microbiol. 34, 105-109. doi: 10.1016/j.syapm.2010.10.001

Figueras, M. J., Levican, A., Collado, L., Inza, M. I., and Yustes, C. (2011b). Arcobacter ellisii sp. nov., isolated from mussels. Syst. Appl. Microbiol. 34, 414-418. doi: 10.1016/j.syapm.2011.04.004

Greene, N. P., Crow, A., Hughes, C., and Koronakis, V. (2015). Structure of a bacterial toxin-activating acyltransferase. Proc. Natl. Acad. Sci. U.S.A. 112, E3058-E3066. doi: 10.1073/pnas.1503832112

Harrass, B., Schwarz, S., and Wenzel, S. (1998). Identification and characterization of Arcobacter isolates from broilers by biochemical tests, antimicrobial resistance patterns and plasmid analysis. Zentralbl. Veterinarmed. B 45, 87-94. doi: 10.1111/j.1439-0450.1998.tb00770.x

Hsu, T. T., and Lee, J. (2015). Global distribution and prevalence of Arcobacter in food and water. Zoonoses Public Health 62, 579-589. doi: 10.1111/zph. 12215

International Commission on Microbiological Specifications for Foods [ICMSF] (2002). Microorganisms in Foods 7: Microbiological Testing in Food Safety Management. New York, NY: Plenum publishers. locations of the mussel farms examined. Angela Cornelius (ESR, New Zealand) is thanked for assisting with preliminary figure preparation.

Jacquiod, S., Brejnrod, A., Morberg, S. M., Abu Al-Soud, W., Sørensen, S. J., and Riber, L. (2017). Deciphering conjugative plasmid permissiveness in wastewater microbiomes. Mol. Ecol. 26, 3556-3571. doi: 10.1111/mec. 14138

Laishram, M., Rathlavath, S., Lekshmi, M., Kumar, S., and Nayak, B. B. (2016). Isolation and characterization of Arcobacter spp. from fresh seafood and the aquatic environment. Int. J. Food Microbiol. 232, 87-89. doi: 10.1016/j. ijfoodmicro.2016.05.018

Land, M., Hauser, L., Jun, S. R., Nookaew, I., Leuze, M. R., Ahn, T. H., et al. (2015). Insights from 20 years of bacterial genome sequencing. Funct. Integr. Genomics 15, 141-161. doi: 10.1007/s10142-015-0433-434

Land, M., Hyatt, D., Jun, S.-R., Kora, G., Hauser, L., Lukjancenko, O., et al. (2014). Quality scores for 32,000 genomes. Stand. Genomic Sci. 9:20. doi: 10.1186/19443277-9-20

Levican, A., Collado, L., Aguilar, C., Yustes, C., Diéguez, A. L., Romalde, J. L., et al. (2012). Arcobacter bivalviorum sp. nov. and Arcobacter venerupis sp. nov., new species isolated from shellfish. Syst. Appl. Microbiol. 35, 133-138. doi: 10.1016/j.syapm.2012.01.002

Levican, A., Collado, L., Yustes, C., Aguilar, C., and Figueras, M. J. (2014). Higher water temperature and incubation under aerobic and microaerobic conditions increase the recovery and diversity of Arcobacter spp. from shellfish. Appl. Environ. Microbiol. 80, 385-391. doi: 10.1128/AEM. 03014-13

Linhartová, I., Bumba, L., Mašín, J., Basler, M., Osička, R., Kamanová, J., et al. (2010). RTX proteins: a highly diverse family secreted by a common mechanism. FEMS Microbiol. Rev. 34, 1076-1112. doi: 10.1111/j.1574-6976. 2010.00231.x

Mandisodza, O., Burrows, E., and Nulsen, M. (2012). Arcobacter species in diarrhoeal faeces from humans in New Zealand. N. Z. Med. J. 125, 40-46.

McFadden, A. M., Heuer, C., Jackson, R., West, D. M., and Parkinson, T. J. (2005). Investigation of bovine venereal campyloacteriosis in beef cow herds in New Zealand. N. Z. Vet. J. 53, 45-52. doi: 10.1080/00480169.2005.36468

Meier-Kolthoff, J. P., Klenk, H. P., and Göker, M. (2014). Taxonomic use of DNA $\mathrm{G}+\mathrm{C}$ content and DNA-DNA hybridization in the genomic age. Int. J. Syst. Evol. Microbiol. 64, 352-356. doi: 10.1099/ijs.0.056994-0

Miller, W. G., Yee, E., and Bono, J. L. (2018). Complete genome sequence of the Arcobacter molluscorum type strain LMG 25693. Microbiol. Resour. Announc. 7:e1293-18. doi: 10.1128/MRA.01293-18

Ministry of Health (2012). A focus on Mâori Nutrition: Findings from the 2008/09 New Zealand Adult Nutrition Survey. Wellington: Ministry of Health.

Mottola, A., Bonerba, E., Figueras, M. J., Pérez-Cataluña, A., Marchetti, P., Serraino, A., et al. (2016). Occurrence of potentially pathogenic Arcobacters in shellfish. Food Microbiol. 57, 23-27. doi: 10.1016/j.fm.2015.12.010

On, S. L. W., Holmes, B., and Sackin, M. J. (1996). A probability matrix for the identification of campylobacters, Helicobacters and allied taxa. J. Appl. Bacteriol. 81, 425-432. doi: 10.1111/j.1365-2672.1996.tb01936.x

On, S. L. W., Miller, W. G., Houf, K., Fox, J. G., and Vandamme, P. (2017). Minimal standards for describing new species belonging to the families Campylobacteraceae and Helicobacteraceae: Campylobacter, Arcobacter, Helicobacter and Wolinella spp. Int. J. Syst. Evol. Microbiol. 67, 5296-5311. doi: 10.1099/ijsem.0.002255

Pérez-Cataluña, A., Salas-Masso, N., and Figueras, M. J. (2018). Arcobacter canalis sp. nov., isolated from a water canal contaminated with urban sewage. Int. J. Syst. Evol. Microbiol. 68, 1258-1264. doi: 10.1099/ijsem.0.002662

Ramees, T. P., Dhama, K., Karthik, K., Rathore, R. S., Kumar, A., Saminathan, M., et al. (2017). Arcobacter: an emerging food-borne zoonotic pathogen, its public health concerns and advances in diagnosis and control - a comprehensive review. Vet. Q. 37, 136-161. doi: 10.1080/01652176.2017.1323355

Rathlavath, S., Kumar, S., and Nayak, B. B. (2017). Comparative isolation and genetic diversity of Arcobacter sp. from fish and the coastal environment. Lett. Appl. Microbiol. 65, 42-49. doi: 10.1111/lam.12743

Seemann, T. (2014). Prokka: rapid prokaryotic genome annotation. Bioinformatics 30, 2068-2069. doi: 10.1093/bioinformatics/btu153 
Toussaint, A., and Chandler, M. (2012). "Prokaryote genome fluidity: toward a system approach of the mobilome," in Bacterial Molecular Networks. Methods in Molecular Biology (Methods and Protocols), Vol. 804, eds J. van Helden, A. Toussaint, and D. Thieffry (New York, NY: Springer), 57-80. doi: 10.1007/9781-61779-361-5_4

Vandamme, P., Falsen, E., Rossau, R., Hoste, B., Segers, P., Tytgat, R., et al. (1991). Revision of Campylobacter, Helicobacter, and Wolinella taxonomy: emendation of generic descriptions and proposal of Arcobacter gen. nov. Int. J. Syst. Bacteriol. 41, 88-103. doi: 10.1099/0020771341-1-88

Vandamme, P., Vancanneyt, M., Pot, B., Mels, L., Hoste, B., Dewettinck, D., et al. (1992). Polyphasic taxonomic study of the emended genus Arcobacter with Arcobacter butzleri comb. nov. and Arcobacter skirrowii sp. nov., an aerotolerant bacterium isolated from veterinary specimens. Int. J. Syst. Bacteriol. 42, 344356. doi: 10.1099/00207713-42-3-344

Ve, T., Williams, S. J., and Kobe, B. (2015). Structure and function of Toll/interleukin-1 receptor/resistance protein (TIR) domains. Apoptosis 20, 250-261. doi: 10.1007/s10495-014-1064-2
Vetting, M. W., S de Carvalho, L. P., Yu, M., Hegde, S. S., Magnet, S., Roderick, S. L., et al. (2005). Structure and functions of the GNAT superfamily of acetyltransferases. Arch. Biochem. Biophys. 433, 212-226. doi: 10.1016/j.abb. 2004.09.003

World Health Organisation [WHO] (2015). Global Action Plan on Antimicrobial Resistance. Geneva: World Health Organization.

Conflict of Interest Statement: The authors declare that the research was conducted in the absence of any commercial or financial relationships that could be construed as a potential conflict of interest.

Copyright (c) 2019 On, Althaus, Miller, Lizamore, Wong, Mathai, Chelikani and Carter. This is an open-access article distributed under the terms of the Creative Commons Attribution License (CC BY). The use, distribution or reproduction in other forums is permitted, provided the original author(s) and the copyright owner(s) are credited and that the original publication in this journal is cited, in accordance with accepted academic practice. No use, distribution or reproduction is permitted which does not comply with these terms. 